\title{
Short communication Effect of altitude on erosive characteristics of concurrent rainfall events in the northern KwaZulu-Natal Drakensberg
}

\author{
W Nel ${ }^{1 *}$, DA Reynhardt ${ }^{1}$ and PD Sumner ${ }^{2}$ \\ ${ }^{1}$ Department of Geography and Environmental Science, University of Fort Hare, Alice 5700, South Africa \\ ${ }^{2}$ Department of Geography, Geoinformatics and Meteorology, University of Pretoria, Pretoria 0002, South Africa
}

\begin{abstract}
High-resolution rainfall data from two stations in the northern KwaZulu-Natal Drakensberg provide insight into the effect of altitude on individual rainfall event characteristics. The effect of altitude on the duration and erosivity (rainfall intensity and kinetic energy) of concurrent rainfall on the escarpment and in the foothills is analysed using 5-min interval data for the calendar year 2003. A cumulative total of 229 rainfall events, measured at the Royal Natal National Park station (1 $392 \mathrm{~m}$ a.m.s.l.) and a temporary station on the escarpment at Sentinel Peak (3 $165 \mathrm{~m}$ a.m.s.l.), were considered, of which 79 rainfall events were found to fall concurrently at the two stations. The data indicate that the concurrent events generate rainfall for longer on the escarpment, but that the amount of rain produced as well as the intensity at which it falls is less than that in the foothills, both in summer and winter. The escarpment appears to limit erosivity, with only 11 events meeting the set criteria for erosivity in the foothills but failing to meet the same criteria on the escarpment. This decrease in erosivity contrasts with previous models for the Drakensberg that demonstrate higher erosivity in the upper reaches, but concurs with studies in mountainous regions elsewhere which found that erosivity decreases with altitude. It is tentatively suggested that the difference in rainfall characteristics could be related to the sources of precipitation and the manner in which the escarpment zone affects the formation and distribution of rainfall. The paper also highlights the need for further research into the association between rainfall structure and synoptic conditions and the effect that the escarpment has on modifying large-scale rainproducing systems in the KwaZulu-Natal Drakensberg.
\end{abstract}

\section{Introduction}

The KwaZulu-Natal Drakensberg reaches altitudes over $3000 \mathrm{~m}$, is part of the Main Escarpment of southern Africa, and is the watershed border between KwaZulu-Natal and Lesotho. South Africa is mostly a semi-arid country but precipitation estimates for the escarpment region range up to 2000 mm/a. (Tyson et al., 1976; Schulze, 1979) and, correspondingly, rainfall erosivity is also expected to be higher in the mountains (Smithen and Schulze, 1982; Seuffert et al., 1999). Contrary to earlier estimates, 2 temporary weather stations placed on the escarpment over a 4-year period (20022005) measured less than $1000 \mathrm{~mm} / \mathrm{a}$ (Nel and Sumner, 2008); total erosivity was also lower than expected (Nel and Sumner, 2007). Snow may contribute an estimated $10 \%$ to precipitation totals (Nel and Sumner, 2005) but the combined contribution of snow, hail and graupel remains unmeasured on the escarpment. From an erosivity perspective, however, it is only the rainfall factor that is considered in soil-loss modelling in the Drakensberg (Smith et al., 2000) and elsewhere (Elwell and Stocking, 1973; Laflen et al., 1991; Morgan et al., 1998; Wischmeier and Smith, 1958; 1978), and it is the altitudinal effects on rainfall erosivity that form the focus of this study.

Erosion modelling around the escarpment area and adjacent Lesotho (Smith et al., 2000; Seuffert et al., 1999) is difficult, due to the almost complete absence of detailed rainfall intensity data at high altitudes. However, Smith et al. (2000) attempted

\footnotetext{
* To whom all correspondence should be addressed.

핀 +27(40) 602 2146; fax: +27(86) 600274 ; e-mail: wnel@ufh.ac.za

Received 24 April 2009; accepted in revised form 31 May 2010.
}

to model soil loss in the Drakensberg using the Universal Soil Loss Equation (USLE) (Wischmeier and Smith, 1978), the Revised Universal Soil Loss Equation (RUSLE) (Renard et al., 1994) and the Soil Loss Estimation Model of Southern Africa (SLEMSA) (Elwell, 1978). Mean seasonal rainfall energy was derived from the relationship between annual kinetic energy and mean annual rainfall for SLEMSA, and long-term average annual erosivity as well as the seasonal distribution of erosivity were obtained from iso-erodent maps for RUSLE and USLE (Smith et al., 2000). Subsequent to this study, actual data became available on rainfall totals and total erosivity in the KwaZulu-Natal Drakensberg (see Nel and Sumner, 2007) and it was suggested that altitude has a pronounced inverse effect on the intensity and cumulative erosivity of high rainfall events (Nel and Sumner, 2007; Nel, 2007). The lack of erosive rainstorms during early and late summer on the escarpment, and significant erosive rains during this period at lower altitudes in the foothills, are provided as reasons for erosive rainfall events on the escarpment producing less cumulative kinetic energy and erosivity (Nel and Sumner, 2007). Given the distances between the different rainfall stations used in these studies, inter-station comparisons were made using individual rainfall events measured locally only. No spatial comparisons of rainfall characteristics were made through the analysis of discrete rainfall events producing rainfall concurrently at more than one location. This paper thus presents the first findings on the effect that the escarpment zone has on the characteristics of individual rainfall events that simultaneously produce rain on the escarpment and in the foothills. The kinetic energy of these rainfall events was analysed to test the hypothesis that rainfall erosivity decreases with an increase in altitude. 


\section{Study sites and methodology}

Rainfall was recorded in the northern Drakensberg at Sentinel Peak $\left(28.74^{\circ} \mathrm{S}, 28.89^{\circ} \mathrm{E}, 3165 \mathrm{~m}\right.$ a.m.s.l.) and in Royal Natal National Park (RNNP) $\left(28.68^{\circ} \mathrm{S}, 28.95^{\circ} \mathrm{E}, 1392 \mathrm{~m}\right.$ a.m.s.l). These stations are located near the north-eastern section of the Lesotho border with South Africa; the Sentinel Peak site is on the escarpment and the RNNP site is in the foothills to the north-east. A clear escarpment zone exists between the 2 stations, which are less than $8 \mathrm{~km}$ from each other but have an altitudinal difference of $1773 \mathrm{~m}$.

Rainfall data were collected using Davis-MC Systems ${ }^{\circ}$ automated tipping-bucket rain gauges. These rain gauges have a $163 \mathrm{~mm}$ collection diameter and log total rainfall every $5 \mathrm{~min}$ on a tipping resolution of $0.2 \mathrm{~mm}$. The gauges have been calibrated against South African Weather Services rain-gauges ( Nel and Sumner, 2005). Some rain-catch deficiency can be expected due to windy conditions, possibly approaching $20 \%$ (Schulze, 1979), but observations by the authors are that both sites can experience windy conditions, particularly during thunderstorms. No wind data are available for the escarpment region. Nonetheless, intensity and erosivity is derived from rainfall measured at the surface, or point of impact, with a rain-gauge. Thus, wind deficiency is of little consequence here as wind-blown rain will simply impact on erosivity measurements elsewhere.

The data analysed here were collected during the logging period in 2003 and the records from the 2 stations were analysed and ordered into individual rainfall events. A rainfall event (whether erosive or non-erosive) was defined as one in which at least $0.5 \mathrm{~mm}$ of precipitation is recorded and which is isolated by at least a $3 \mathrm{~h}$ rain-free period ( $\mathrm{Nel}, 2008)$. The data were then sorted to identify rainfall events measured at both stations that started within $3 \mathrm{~h}$ of each other. The close proximity of the sites along an altitudinal transect allows for direct comparison between events arising from the same localised weather system.

The depth of rainfall (mm), duration of the event (minutes), and the maximum 5 -min intensity $(\mathrm{mm} / \mathrm{h}$ ) were analysed from the individual rainfall events. Kinetic energy potential of the rainfall events was also considered. Work by Elwell and Stocking (1973) in Zimbabwe suggests that for subtropical climates the kinetic energy content of rainfall can be predicted by the equation:

$$
\mathrm{Ek}=(29.82-127.51 / \mathrm{I}) \text { in } \mathrm{J} / \mathrm{m} 2 \cdot \mathrm{mm}
$$

where:

intensity, I, is in $\mathrm{mm} / \mathrm{h}$.

This equation has also been adopted for use in the SLEMSA and was applied by Schulze (1980) in a first assessment of the kinetic energy of rainfall in South Africa. It was also used to assess the spatial distribution of erosive storm events in the Drakensberg (Nel and Sumner, 2007). In order to allow for consistency with previous studies in southern Africa and specifically in the Drakensberg, the equation by Elwell and Stocking (1973), Eq. (1), is used here to assess the 5-min incremental kinetic energy content derived from rainfall intensity. In addition, from these corresponding individual rain events, the erosive rain events were isolated through the modified definition of Stocking and Elwell (1976). An erosive event was defined as having rainfall exceeding $12.5 \mathrm{~mm}$ and maximum 5 -min intensity which exceeds $25 \mathrm{~mm} / \mathrm{h}$ and which is separated by a rain-free period of $3 \mathrm{~h}$.

\section{Results}

When applying the definition of a rain event, 113 and 116 rain events were recorded during 2003 for Sentinel Peak and Royal Natal National Park, respectively. Of the 113 and 116 rainfall events measured, 79 rainfall events were isolated that produced rainfall simultaneously at Sentinel Peak and RNNP. The characteristics of the rainfall events measured at the respective stations are given in Table 1. On average, for the same event, the duration of rainfall at Sentinel Peak is longer, but the amount of rain is less than at RNNP. Sentinel Peak also recorded lower rainfall intensities as well as lower potential kinetic energies from events than at RNNP. The average maximum 5-min rainfall intensities of the rainfall events measured on the escarpment is approximately $50 \%$ of the measurements in the foothills.

The seasonal distribution of rainfall-event characteristics for the 79 events is given in Table 2. During summer, total rainfall and kinetic energies of the rainfall events measured at the 2 stations are quite similar, but the rainfall intensities are markedly different (Table 2). Rainfall events in summer produce higher maximum intensities in the foothills (RNNP) then on the escarpment. During the winter months, the rain events produced significantly less rainfall, rainfall intensity and kinetic energy on the escarpment (Table 2).

From the individual rain events that produce rain at both stations, the erosive rain events were isolated through the modified definition of Stocking and Elwell (1976). Of the 79 events, 12 events were deemed to have erosive characteristics at either the Sentinel Peak or RNNP site. Of the 12 events, 11 events showed erosive characteristics at RNNP, but not at the Sentinel, while only 1 event showed erosive characteristics at Sentinel and not at RNNP. No event that was measured had erosive characteristics at both stations.

The characteristics of the erosive rainfall events as measured at RNNP, with the corresponding rainfall characteristics measured at Sentinel Peak, are given in Table 3. While the individual rainfall events produced erosive rainfall in the foothills, the rain falling at the same time on the escarpment did not meet

\begin{tabular}{|c|c|c|c|c|c|c|c|}
\hline \multicolumn{8}{|c|}{$\begin{array}{l}\text { Table } 1 \\
\text { Rain-event characteristics for the } 79 \text { rainfall events measured concurrently at Sentinel Peak } \\
\text { and Royal Natal National Park }\end{array}$} \\
\hline & $\begin{array}{l}\text { Average } \\
\text { duration } \\
\text { of rainfall } \\
\text { event (min) }\end{array}$ & $\begin{array}{l}\text { Total rainfall } \\
\text { from events } \\
\quad(\mathrm{mm})\end{array}$ & $\begin{array}{l}\text { Mean } \\
\text { rainfall per } \\
\text { event }(\mathrm{mm})\end{array}$ & $\begin{array}{c}\text { Average } \\
\text { maximum } \\
5-\mathrm{min} \\
\text { intensity } \\
(\mathrm{mm} / \mathrm{h})\end{array}$ & $\begin{array}{l}\text { Total kinetic } \\
\text { energy } \\
\left(\mathrm{J} / \mathrm{m}^{2} \cdot \mathrm{mm}\right)\end{array}$ & $\begin{array}{c}\text { Average } \\
\text { kinetic } \\
\text { energy per } \\
\text { event } \\
\left(\mathrm{J} / \mathrm{m}^{2} \cdot \mathrm{mm}\right)\end{array}$ & $\begin{array}{c}\text { Average of } \\
\text { mean 5-min } \\
\text { rainfall } \\
\text { intensity } \\
(\mathrm{mm} / \mathrm{h})\end{array}$ \\
\hline Sentinel & 314 & 545.3 & 6.9 & 8.7 & 4041 & 52 & 3.7 \\
\hline RNNP & 286 & 628.9 & 8.0 & 16.1 & 5143 & 65 & 5.4 \\
\hline
\end{tabular}




\begin{tabular}{|c|c|c|c|c|c|c|}
\hline \multicolumn{7}{|c|}{$\begin{array}{c}\text { Table } 2 \\
\text { Seasonal distribution of the } 79 \text { rainfall events and their characteristics at Sentinel Peak and } \\
\text { Royal Natal National Park }\end{array}$} \\
\hline Season & \begin{tabular}{|l|} 
Station \\
name
\end{tabular} & No of events & $\begin{array}{c}\text { Average } \\
\text { duration of } \\
\text { rainfall event } \\
\text { (minutes) }\end{array}$ & $\begin{array}{l}\text { Total rainfall } \\
(\mathrm{mm})\end{array}$ & $\begin{array}{c}\text { Average of } \\
\text { maximum 5-min } \\
\text { intensities } \\
(\mathrm{mm} / \mathrm{h})\end{array}$ & $\begin{array}{l}\text { Total kinetic } \\
\text { energy } \\
(\mathrm{J} / \mathrm{m} 2 \cdot \mathrm{mm})\end{array}$ \\
\hline \multirow[t]{2}{*}{ Summer } & Sentinel & \multirow[t]{2}{*}{64} & 323 & 491.7 & 9.8 & 3813 \\
\hline & RNNP & & 272 & 507.0 & 15.2 & 4110 \\
\hline \multirow[t]{2}{*}{ Winter } & Sentinel & \multirow[t]{2}{*}{15} & 319 & 53.6 & 3.4 & 228 \\
\hline & RNNP & & 420 & 122.6 & 16.5 & 1033 \\
\hline
\end{tabular}

the criteria for total rainfall $(12.5 \mathrm{~mm})$ as well as intensity of rainfall $(25 \mathrm{~mm} / \mathrm{h})$ for it to be considered as erosive. Only 3 storms (Nos. 2, 9 and 11) met the criteria for total rainfall on the escarpment but the intensity at which the rain fell was not deemed to be of an erosive nature (Table 3). These 11 erosive events have a dramatic impact on the total kinetic energies measured at the low altitude station. At RNNP, these 11 rainfall events recorded $2882 \mathrm{~J} / \mathrm{m} 2 \cdot \mathrm{mm}$, which constituted $56 \%$ of the total kinetic energy measured from all 79 concurrent events (Table 3).

\section{Discussion}

Seasonal rainfall in the Drakensberg is associated with the synoptic sources of precipitation. During summer, largescale line- and orographically-induced thunderstorms (as well as thunderstorms associated with mesoscale convective complexes) produce rain, and in winter cold fronts pass through the area (Tyson et al., 1976; Maddox, 1980). Cold fronts are associated with mid-latitudinal depressions (Hurry and Van Heerden, 1982) that develop in the mid- to high-latitude southwest Atlantic. Winter rainfall events show a marked decrease in total rainfall, kinetic energy produced, and intensity at which rainfall falls on the escarpment. However, it is not only during winter that differences between the foothills and escarpment are recorded. In general, for the same summer rainfall event, rainfall on the escarpment is of a longer duration, but rainfall depth is less, than in the foothills. The average potential kinetic energy and mean 5-min rainfall intensity is also higher in the foothills; and this is further enforced by the erosive rainfall events. The characteristics of the discrete erosive rainfall events producing rainfall in the foothills and the escarpment show that when the rainfall event meets the criteria for erosivity (intensity and depth) in the foothills, it does not produce erosive rainfall on the escarpment. The escarpment edge is thus less likely to receive erosive rainfall even if erosive rainfall is simultaneously generated in the foothills. Studies in mountainous areas elsewhere show similar results. In the Columbian Andes, rainfall intensity seems affected by elevation, with consistently lower rainfall intensity (I30)
Table 3

Characteristics of the 11 erosive rainfall events measured at Royal Natal National Park and the corresponding rain event characteristic at Sentinel Peak

\begin{tabular}{|c|c|c|c|c|c|}
\hline $\begin{array}{l}\text { Event } \\
\text { no }\end{array}$ & $\begin{array}{l}\text { Station } \\
\text { name }\end{array}$ & $\begin{array}{l}\text { Duration of } \\
\text { event (min) }\end{array}$ & $\begin{array}{l}\text { Total rain } \\
\text { for event } \\
(\mathrm{mm})\end{array}$ & $\begin{array}{c}\text { Maximum } \\
\text { 5-min } \\
\text { intensity } \\
\text { (mm/h) }\end{array}$ & $\begin{array}{c}\text { Total } \\
\text { potential } \\
\text { kinetic } \\
\text { energy } \\
\left(\mathrm{J} / \mathrm{m}^{2} \cdot \mathrm{mm}\right)\end{array}$ \\
\hline \multirow[t]{2}{*}{1} & RNNP & 50 & 14.8 & 57.6 & 119 \\
\hline & Sentinel & 195 & 3.6 & 19.2 & 40 \\
\hline \multirow[t]{2}{*}{2} & RNNP & 170 & 18.6 & 76.8 & 158 \\
\hline & Sentinel & 925 & 12.8 & 4.8 & 20 \\
\hline \multirow[t]{2}{*}{3} & RNNP & 295 & 16.2 & 33.6 & 173 \\
\hline & Sentinel & 325 & 8.0 & 9.6 & 30 \\
\hline \multirow[t]{2}{*}{4} & RNNP & 110 & 19.4 & 60.0 & 174 \\
\hline & Sentinel & 170 & 2.6 & 9.6 & 29 \\
\hline \multirow[t]{2}{*}{5} & RNNP & 70 & 18.0 & 50.4 & 177 \\
\hline & Sentinel & 325 & 7.0 & 4.8 & 16 \\
\hline \multirow[t]{2}{*}{6} & RNNP & 430 & 16.0 & 38.4 & 178 \\
\hline & Sentinel & 600 & 9.8 & 16.8 & 63 \\
\hline \multirow[t]{2}{*}{7} & RNNP & 1005 & 26.0 & 40.8 & 194 \\
\hline & Sentinel & 780 & 11.8 & 14.4 & 90 \\
\hline \multirow[t]{2}{*}{8} & RNNP & 305 & 42.4 & 81.6 & 386 \\
\hline & Sentinel & 90 & 6.8 & 14.4 & 89 \\
\hline \multirow[t]{2}{*}{9} & RNNP & 820 & 38.2 & 36.0 & 422 \\
\hline & Sentinel & 395 & 15.2 & 7.2 & 19 \\
\hline \multirow[t]{2}{*}{10} & RNNP & 1750 & 60.0 & 28.8 & 448 \\
\hline & Sentinel & 1755 & 61.6 & 16.8 & 437 \\
\hline \multirow[t]{2}{*}{11} & RNNP & 800 & 39.2 & 36.0 & 453 \\
\hline & Sentinel & 390 & 19.2 & 14.4 & 185 \\
\hline \multirow[t]{2}{*}{ TOTAL } & RNNP & 3050 & 308.8 & - & 2882 \\
\hline & Sentinel & 4195 & 158.4 & - & 1018 \\
\hline
\end{tabular}

values at the highest altitude rainfall station (Hoyos et al., 2005). Millward and Mersey (1999) found that erosivity and precipitation in southwest Mexico increased with elevation, while Mikhailova et al. (1997) found that in Honduras erosivity decreased with an increase in altitude. This study also examined datasets from Costa Rica, Sri Lanka and the southeastern United States and found that in all cases there was an inverse relationship between rainfall erosivity and elevation (Mikhailova et al., 1997).

Orographically-induced storms are probably the most frequent of all summer storms in the KwaZulu-Natal Drakensberg (Tyson et al., 1976). By midday the lower atmosphere receives moisture from winds blowing from the plain to the mountain. Subsidence in the upper westerly winds causes a temperature 
discontinuity between the upper and lower wind systems. The plain-mountain wind ascends up the escarpment and slope convection along the escarpment increasingly releases convective instability with resultant cloud development (Tyson et al., 1976). The decrease in the production of erosive rainfall and kinetic energy with altitude, from rainfall events in summer, could therefore be directly related to the way in which orographic storms develop in the Drakensberg, such that peak rainfall is produced before maximum altitude is reached. This also seems to be the case in the Andes where rainfall trends suggest a relationship between elevation and erosivity, with the latter increasing to about $1750 \mathrm{~m}$ and then decreasing to lower values at the highest elevations (2 $120 \mathrm{~m}$ ) (Hoyos et al., 2005). However, the relationship between synoptic conditions and rainfall structure and altitudinal distribution in the Drakensberg remains unclear.

The data presented here also suggest that the escarpment zone somehow influences the effectiveness of the winter cold fronts in producing substantial rainfall at high altitude. The cold fronts move across southern Africa in a west-northwest to east-southeast direction and are generally deflected parallel to the line of the South African escarpment (Tyson et al., 1976). Cold-frontal rainfall is normally associated with low-level stratocumulus clouds and deflection of the cold front track and the low level of the cloudbank could possibly be the reason for the high altitude areas receiving less winter rainfall, at lower intensities and energy, than in the foothills.

\section{Summary}

Concurrent rainfall events at 2 sites in the northern KZN Drakensberg are analysed here. Findings show that it rains for longer on the escarpment, but that the amount of rain produced as well as the intensity at which it falls is lower on the escarpment than in the foothills. This is contrary to earlier findings, and the escarpment zone clearly reduces the erosivity of rainfall in comparison to the foothills. These findings are evident both in summer and winter, where rainfall is produced by different weather systems. The data tentatively suggest that such altitudinal differences in rainfall characteristics could possibly be related to the sources of rainfall and how the escarpment zone affects the formation and distribution of rain. Further research is needed to assess the association between rainfall structure and synoptic conditions, especially the effect that the escarpment has on modifying large-scale rain-producing systems in the KwaZulu-Natal Drakensberg. However, it is noted that differences in wind speed at the 2 sites could have skewed the results, due to catch deficiency, and further data are required to evaluate the role of wind, and also from other areas of the escarpment to clarify spatial trends and assist in generalised erosivity mapping of the high mountain area.

\section{Acknowledgements}

The Department of Geography, Geoinformatics and Meteorology at the University of Pretoria supplied the Davis-MC Systems (D-MCS) equipment. The Govan Mbeki Research and Development Centre at the University of Fort Hare supplied additional funding.

\section{References}

ELWELL HA (1978) Modelling soil losses in southern Africa. $J$. Agric. Eng. Res. 23 117-127.

ELWELL HA and STOCKING MA (1973) Rainfall parameters for soil loss estimation in a subtropical climate. J. Agric. Eng. Res. 18 169-177.

HOYOS N, WAYLEN PR AND JARAMILLO A (2005) Seasonal and spatial patterns of erosivity in a tropical watershed of the Colombian Andes. J. Hydrol. 314 177-191.

HURRY L and VAN HEERDEN J (1982) Southern Africa's Weather Patterns: A Guide to the Interpretation of Synoptic Maps. Afrika Limited, Cape Town, South Africa.

LAFLEN JM, LANE LJ and FOSTER GR (1991) WEPP. A new generation of erosion prediction technology. J. Soil Water Conserv. 46 34-38.

MADDOX RA (1980) Mesoscale convective complexes. Bull. Amer. Meteorol. Soc. 61 1374-1387.

MIKHAILOVA EA, BRYANT RB, SCHWAGER SJ and SMITH SD (1997) Predicting rainfall erosivity in Honduras. Soil Sci. Soc. Am. J. 61 273-279.

MILLWARD AA and MERSEY JE (1999) Adapting the RUSLE to model soil erosion potential in a mountainous tropical watershed. Catena 38 109-129.

MORGAN RPC, QUINTON JN, SMITH RE, GOVERS G, POESEN JWA, AUERSWALD K, CHISCI G, TORRI D and STYCZEN ME (1998) The European Soil Erosion Model (EUROSEM): A dynamic approach for predicting sediment transport from fields and small catchments. Earth Surf. Proc. Landf. 23 527-544.

NEL W (2007) Intra-storm attributes of extreme storm events in the Drakensberg, South Africa. Phys. Geogr. 28 158-169.

NEL W (2008) Observations on daily rainfall events in the KwaZuluNatal Drakensberg. Water SA 34 (2) 271-274.

NEL W and SUMNER PD (2005) First rainfall data from the KZN Drakensberg escarpment edge (2002 and 2003). Water SA 31 (3) 399-402.

NEL W and SUMNER PD (2007) Intensity, energy and erosivity attributes of rainstorms in the KwaZulu-Natal Drakensberg, South Africa. S. Afr. J. Sci. 103 398-402.

NEL W and SUMNER PD (2008) Rainfall and temperature attributes on the Lesotho-Drakensberg escarpment edge, southern Africa. Geogr. Ann. 90A (1) 97-108.

RENARD KG, FOSTER GR, WEESIES GA, McCOOL DK and YODER DC (1994) RUSLE User Guide. Predicting soil erosion by water: a guide to conservation planning with the Revised Universal Soil Loss Equation. Agricultural Handbook 703, USDA, Washington, DC.

SCHULZE RE (1979) Hydrology and Water Resources of the Drakensberg. Natal Town and Regional Planning Commission, Pietermaritzburg, South Africa. 179 pp.

SCHULZE RE (1980) The distribution of kinetic energy of rainfall in South Africa - A first assessment. Water SA 6 49-58.

SEUFFERT O, HERRIG K, OLLESH G and BUSCHE D (1999) REI: An integrated rainfall erosivity index for assessing and correlating rainfall structure, runoff and erosion. Geoökodynamik 20 1-54.

SMITH HJ, VAN ZYL AJ, CLAASSENS AS, SCHOEMAN JL and LAKER MC (2000) Soil loss modelling in the Lesotho Highlands Water Project catchment area. S. Afr. Geogr. J. 82 64-69.

SMITHEN AA and SCHULZE RE (1982) The spatial distribution in southern Africa of rainfall erosivity for use in the Universal Soil Loss Equation. Water SA 8 74-78.

STOCKING MA and ELWELL HA (1976) Rainfall erosivity over Rhodesia. Inst. Br. Geogr. Trans. 1 231-245.

TYSON PD, PRESTON-WHYTE RA and SCHULZE RE (1976) The Climate of the Drakensberg. Natal Town and Regional Planning Commission, Pietermaritzburg. 82 pp.

WISCHMEIER WH, and SMITH DD (1958) Rainfall energy and its relation to soil loss. Trans. Am. Geophys. Un. 39 285-291.

WISCHMEIER WH and SMITH DD (1978) Predicting Rainfall Erosion Losses. Agricultural Handbook 537. USDA, Washington, DC. 